\title{
Correlation between ground state properties and plasmon energy of ternary chalcopyrite semiconductors.
}

\author{
S.K.Gorai ${ }^{1}$, Parmanand Mahto ${ }^{2}$ \\ ${ }^{\text {I}}$ (Department of physics,Tata College Chaibasa/ KolhanUniversity, India) \\ ${ }^{2}$ (Department of physics, Vinoba Bhave University,Hazaribagh-825301,India)
}

\begin{abstract}
A simple relation between microhardness, plasmon energy, bulk modulus, electronic polarisability are given for ternary chalcopyrite semiconductors. Microhardness has been estimated from plasmon energy by proposing a linear relation between them.From microhardness, bulk modulus has been estimated and refractive index is estimated from bulk modulus and subsequently polarisability has been estimated. The results are in excellent agreement with the available experimental data and earlier researchers.
\end{abstract}

Keywords -Plasmon energy,Bulkmodulus,Microhardness, Chalcopyrites,Polarisability.

\section{INTRODUCTION}

The ternary chalcopyrite semiconductors are technologically important group of semiconductors and have been studied extensively in last three decades,especially for their linear and nonlinear optical properties[12].The broad range of optical band gap and carrier mobilities offered by the binary $\mathrm{ABC}_{2}$ semiconductors as well as their ability to form various solid solution and to accommodate different dopants has led to their emergence as technologically significant device materials, including application in photovoltaic solar cells, light emmiting diodes, infrared detectors etc. Although different methods of materials preparation for these chalcopyrites (I-III- $-\mathrm{VI}_{2}$ and II-IV- $\mathrm{V}_{2}$ ) compounds have been suggested [3-6].These semiconductors crystallize in the chalcopyrite structure which is deduced from that of zinc blende by the replacement of cationic sublattice by two different atomic species.This induces the doubling of unit cell in a direction, which is conventionally called $\mathrm{c}$ and a tetragonal distortion. This distortion is characterized by the parameter $\eta=c / 2 a$, where a and $c$ are lattice parameters and by the anion displacement $\mathrm{u}=0.25+\left(\mathrm{d}^{2}{ }_{\mathrm{A}-\mathrm{C}}+\mathrm{d}^{2}{ }_{\mathrm{B}-\mathrm{C}}\right) / \mathrm{a}^{2}$ from its position in the cubic cell, where $\mathrm{d}_{\mathrm{A}-\mathrm{C}}$ and $\mathrm{d}_{\mathrm{B}-\mathrm{C}}$ are the cation-anion distances. Because of the added structural $(\eta, \mathrm{u})$ and chemical $\left(\mathrm{d}_{\mathrm{A}-\mathrm{C}}\right.$ and $d_{B-C}$ ) degrees of freedom relative to their binary analogue, the ternary semiconductors exhibit a wide range of interesting physical chemical properties. The knowledge of many of the physicochemical properties that are essential for designing appropriate conditions for the growth of bulk single crystals and of high quality epitaxial layers is still inadequate.In this regard some mechanical properties such as microhardness, bulk modulus and optical properties such as polarisability have been studied.There have been various experimental and theoretical calculations based on empirical relations which have become an essential part of material research.Empirical formulae are mostly found to be simple, easy to use and gave a better value for physical parameters such as energy gap,dielectric constants,crystal ionicity, bondlength of semiconductors, empirical radii, electronegativity,ionicity and plasmon energy.The basic properties of molecules and solids are explained with the character of chemical bond. In chemical bond it is the valence electrons that takes part. These electrons reside in the outermost shell of the atom. Verma and Bhardwaj[7-8],Verma and Sharma[9-11] have recently calculated the electronic,mechanical and optical properties of semiconductors and insulators with the help of ionic charge theory of solids .In this paper we have calculated microhardness, bulk modulus, polarisability of $\mathrm{A}^{\mathrm{I}} \mathrm{B}^{\mathrm{III}} \mathrm{C}^{\mathrm{VI}}{ }_{2}$ and $\mathrm{A}^{\mathrm{II}} \mathrm{B}^{\mathrm{IV}} \mathrm{C}^{\mathrm{V}}$ ternary chalcopyrites which are in excellent agreement with the previous estimation $[12,13]$.A fairly good agreement has been obtained between them.

\section{THEORY, RESUlTS AND CALCULATION}

Microhardness is not an intrinsic material property since it represents the resistance of material to plastic deformation and it involves the nature of dislocation motion. An empirical relation between microhardness $(\mathrm{H})$ and bonding parameters like valency of the atom in a crystal ,melting point and ionicity have been developed for $A^{\mathrm{N}} \mathrm{B}^{8-\mathrm{N}}$ tetrahedral semiconductors and later on extended to $\mathrm{A}^{\mathrm{N}-1} \mathrm{~B}^{\mathrm{N}+1} \mathrm{C}_{2}{ }^{8-\mathrm{N}}(\mathrm{N}=2,3)$ semiconductors. Ternary chalcopyrites of general compositions $\mathrm{A}^{\mathrm{I}} \mathrm{B}^{\mathrm{III}} \mathrm{C}_{2}{ }^{\mathrm{VI}}$ and $\mathrm{A}^{\mathrm{II}} \mathrm{B}^{\mathrm{IV}} \mathrm{C}_{2}{ }^{\mathrm{V}}$ can be considered as similar [15-17] to those of $\mathrm{A}^{\mathrm{II}} \mathrm{B}^{\mathrm{VI}}$ and $\mathrm{A}^{\mathrm{II}} \mathrm{B}^{\mathrm{V}}$ binary tetrahedral semiconductors. According to Samanta et al.[18] microhardness (H) of $\mathrm{A}^{\mathrm{I}} \mathrm{B}^{\mathrm{III}} \mathrm{C}_{2}{ }^{\mathrm{VI}}$ and $\mathrm{A}^{\mathrm{II}} \mathrm{B}^{\mathrm{IV}} \mathrm{C}_{2}{ }^{\mathrm{V}}$ semiconductors may be expressed as

$$
H=H_{B}\left(\frac{B}{B-V}\right)\left(\frac{1}{P}\right)^{1 / 2}\left(\frac{1}{d^{2}}\right)\left(\frac{e_{a} e_{c}}{e^{2}}\right)\left(1-\frac{f_{i}}{F_{i}}\right)\left(\frac{T_{m}}{T}\right)
$$


where $H_{B}$ is a numerical constants with the unit of $10^{-14} \mathrm{~kg}$. The term $\left(\frac{B-V}{V}\right)$ may be said to measure the availability of states for electron transfer where $B$ denotes the limiting number of band states per metal atom of interacting set of atoms (e.g. $B=8$ for sp and 12 for sd bands), $V$ is the number of valence electron per atom contributing to bonding, $P$ is the mean periodicity of atom, $d$ is the effective nearest neighbour distance $e_{a}$ and $e_{c}$ are valence numbers of anion and cation and $\mathrm{e}$ is the valence of pure covalent crystals $f_{i}$ is the mean value of ionicity of A-C and B-C bonds in ternary chalcopyrites. $F_{i}=0.785$ is the critical ionicity as defined as dielectric theory of Phillip[15] and Van Vechten [16] which separates four fold and six fold coordination scheme.Since equation(1) depends on the number of valence electrons which changes when a metal forms a compounds. These valence electrons when collectively oscillate in a solid is known as plasma oscillation in a solid. These oscillations in which all the valence or conduction electrons participate are a consequence both of inertia of the electrons and of their repulsive coulomb interaction. Such plasma oscillation in a solid can be excited in the electron gas either by fast energetic bombarding electrons [19,20] or during X-ray and Auger electron transitions[21,22].A plasmon is the quantum of elementary excitations associated with high frequency collective motion [23].Plasmon are studied by means of electron energy loss spectroscopy (EELS) and have been reported in recent years [24-28].Therefore we thought it would be of interest to propose an empirical relation between microhardness and plasmon energy of ternary chalcopyrites. We are of the view that the microhardness $(\mathrm{H})$ of $\mathrm{A}^{\mathrm{I}} \mathrm{B}^{\mathrm{III}} \mathrm{C}_{2}{ }^{\mathrm{VI}}$ and $\mathrm{A}^{\mathrm{II}} \mathrm{B}^{\mathrm{IV}} \mathrm{C}_{2}{ }^{\mathrm{V}}$ semiconductors can be estimated using plasmon energy by the following relation as

$\mathrm{H}=\mathrm{C}\left(\hbar \omega_{p}\right)-\mathrm{D}$

where $\mathrm{C}$ and $\mathrm{D}$ are constants, The values of $\mathrm{C}$ and $\mathrm{D}$ be $20.333,130.86$ for $\mathrm{A}^{\mathrm{I}} \mathrm{B}^{\mathrm{III}} \mathrm{C}_{2}{ }^{\mathrm{VI}}$ and $271.64,3560.6$ for $\mathrm{A}^{\mathrm{II}} \mathrm{B}^{\mathrm{IV}} \mathrm{C}_{2}{ }^{\mathrm{V}}$ semiconductors. The plasmon energy of ternary chalcopyrites is given by

$\hbar \omega_{p}=\frac{4 \Pi N e^{2}}{m}$

where $\mathrm{N}$ is the valence electron density, e is the charge and $\mathrm{m}$ is the mass of the electron. In chalcopyrite compounds the effective number valence electrons of individual bond properties as

$N_{e}^{\mu}=\frac{n_{e}^{\mu}}{v_{b}^{\mu}}$

where $n_{e}^{\mu}=\frac{z_{\alpha}^{\mu}}{N_{\alpha}^{\mu}}+\frac{z_{\beta}^{\mu}}{N_{\beta}^{\mu}}$

$n_{e}^{\mu}$ is the number of valence electrons of atom $\alpha$ and $\beta . \quad N_{\alpha}^{\mu}$ and $N_{\beta}^{\mu}$ are the co-ordination number of atoms and $v_{b}^{\mu}$ is the bond volume. The bond volume is

$v_{b}^{\mu}=4 \frac{d_{\alpha \beta}^{3}}{3 \sqrt{3}}$

for chalcopyrite structure where $d_{\alpha \beta}$ is the mean value bond length of A-C and B-C bond present in these ternary chalcopyrites. The plasmon energy can be written as

$\hbar \omega_{p}=28.8 \sqrt{\frac{Z \sigma}{M}} \quad(\mathrm{eV})$

where $\mathrm{Z}$ is the effective number of valence electrons taking part in plasma oscillations, $\sigma$ is the specific gravity and $\mathrm{M}$ is the molecular weight, $\hbar \omega_{p}$ is the mean value of plasmon energy of individual bond length $\hbar \omega_{p}=\left(\hbar \omega_{p A-C}+\hbar \omega_{p_{B-C}}\right) / 2$ and $\mathrm{d}$ is the mean value of bond length. The bulk modulus defines its resistance to volume change when compressed. Both experimental and theoretical result suggest that the bulkmodulus is a critical single material property to indicate hardness Neuman [13] has proposed the bulkmodulus microhardness relationship in $\mathrm{A}^{\mathrm{II}} \mathrm{B}^{\mathrm{IV}} \mathrm{C}_{2} \mathrm{v}$ chalcopyrite semiconductors by the following relation

$\mathrm{B}=\frac{C V_{0}^{k} H}{T_{m}}$ 
where $C$ and $k$ are adjustable parameters.Cohen [30] and Lam et al [38] have investigated the bukmodulii and geometrical properties of diamond and ZB solids. Considering Phillips and VanVechten scheme [15,16] cohen has proposed the following empirical relation:

$$
\mathrm{B}=(1971-220 \lambda) d^{-3.5}
$$

where $\lambda$ is an empirical parameter which accounts for the effect of ionicity, $\lambda=0,1,2$ for IV,III-V and II-VI compounds respectively, $d$ is the nearest neighbours distance in $\mathrm{A}^{0}$ and B in GPa. Lam et al [30] has deduced bulk modulii to lattice parameters within the local density formalism and the pseudopotential as

$\mathrm{B}=1971 d^{-3.5}-408(\Delta Z)^{2} d^{-4}$

where $\Delta Z=1$ and 2 for III-V and II-VI semiconductors. The modification of cohens relation (7) given by Grima and Gallardo [33] may be expressed in terms of average nearest neighbour distance and electronic susceptibilities of different bond by the following relation

$\mathrm{B}=(1971-220 \lambda) d^{-3.5}-\left|\chi_{A C}-\chi_{B C}\right|^{2.5}$

where $\lambda=0.72, d=\left(d_{A C}+d_{B C}\right) / 2$ and $\chi_{A C}$ and $\chi_{B C}$ are the electronic susceptibilities of the bond. Recently Reddy et al [39] have studied bulk modulli from microhardness as

$\mathrm{B}=51.538 \mathrm{H} \mathrm{n}^{0.131} \mathrm{f}_{\mathrm{i}} \quad(10)$

(for $\mathrm{A}^{\mathrm{I}} \mathrm{B}^{\mathrm{III}} \mathrm{C}_{2}{ }^{\mathrm{VI}}$ ternary chalcopyrites)

$\mathrm{B}=33.057 \mathrm{H} \mathrm{n}^{0.131} \mathrm{f}_{\mathrm{i}} \quad(11)$

(for $\mathrm{A}^{\mathrm{II}} \mathrm{B}^{\mathrm{IV}} \mathrm{C}_{2} \mathrm{~V}$ ternary chalcopyrites)

where $\mathrm{H}$ is the microhardness, $\mathrm{n}$ is the refractive index and $f_{i}$ is the ionicity of ternary chalcopyrite semiconductors. We propose a linear empirical relation between microhardness and bulk modulus of ternary chalcopyrite semiconductors.From the proposed relation we estimate bulk modulus from microhardness(calculated). The proposed relation as

$\mathrm{B}=\mathrm{M}(\mathrm{H})-\mathrm{N}$

where $\mathrm{M}$ and $\mathrm{N}$ are constants, their numerical values are $\mathrm{M}=0.0767, \mathrm{~N}=32.704$ for II-IV- $\mathrm{V}_{2}$ compounds and $\mathrm{M}=0.8135, \mathrm{~N}=-85.703$ for $\mathrm{I}-\mathrm{III}-\mathrm{VI}_{2}$ for compounds respectively. we propose another relation between bulk modulus and refractive index for evaluating the refractive index of $\mathrm{A}^{\mathrm{I}} \mathrm{B}^{\mathrm{III}} \mathrm{C}_{2}{ }^{\mathrm{VI}}$ and $\mathrm{A}^{\mathrm{II}} \mathrm{B}^{\mathrm{IV}} \mathrm{C}_{2}{ }^{\mathrm{V}}$ chalcopyrite respectively. The proposed equation as

$n=A e^{-K B}$

where $n$ is the refractive index of ternary chalcopyrites and $\mathrm{A}, \mathrm{K}$ are constants and their values are $\mathrm{A}$ $=4.154, \mathrm{~K}=0.0028$ for $\mathrm{II}-\mathrm{IV}-\mathrm{V}_{2}$ semiconductors and $\mathrm{A}=3.8263, \mathrm{~K}=-0.0052$ for $\mathrm{I}-\mathrm{III}-\mathrm{VI}_{2}$ semiconductors respectively subsequently polarisability is estimated using Claussius -Mossotti equation as

$\alpha=0.395 \times 10^{-24}\left[\frac{n^{2}-1}{n^{2}+2}\right] \times \frac{M}{d} \mathrm{~cm}^{3}$

where $\alpha$ is the electronic polarisability, $M$ and $d$ are molecular weight and density of the chalcopyrites.

\section{Conclusion}

We have estimated the microhardness of $\mathrm{A}^{\mathrm{I}} \mathrm{B}^{\mathrm{III}} \mathrm{C}_{2}{ }^{\mathrm{VI}}$ and $\mathrm{A}^{\mathrm{II}} \mathrm{B}^{\mathrm{IV}} \mathrm{C}_{2} \mathrm{~V}$ semiconductors using plasmon energy of chalcopyrite semiconductors. From microhardness we estimate bulk modulus of semiconductors and subsequently polarisability is estimated from calculated values bulk modulus using claussius -Mossotti equation. The estimated values of polarisability of ternary chalcopyrites are given in table 3 and 4 for the comparison with other researchers. The plasmon energy is a key parameter for estimating optical and mechanical properties of the compounds concerned. We find that plasmon energy has a linear relation with the experimental values of microhardness and microhardness (calculated) has a linear relation with experimental value of bulk modulus. The estimated values of bulkmodulus and Microhardness of ternary chalcopyrites and their experimental values are given in table 1 and table 2 for the comparison. It also appears that our calculated values agree well with the experimental ones. Amongst the $\mathrm{A}^{\mathrm{I}} \mathrm{B}^{\mathrm{III}} \mathrm{C}_{2}{ }^{\mathrm{VI}}$ and $\mathrm{A}^{\mathrm{II}} \mathrm{B}^{\mathrm{IV}} \mathrm{C}_{2}{ }^{\mathrm{V}}$ compounds the former group materials posseses greater value $\mathrm{H}$ than the latter because of more covalent character of the former. On comparing the bulk modulus amongst it is seen that they all decrease for sulphide to selenide to telluride in case of $\mathrm{Cu}-\mathrm{III}-\mathrm{VI}_{2}$ compounds and the same features follows for $\mathrm{Ag}$ compounds. 


\section{REFERENCES}

[1] H Metzner,U Reislöhner ,J Cieslak,W Witthuhn, T Hahs T and Kraüßlichn, J Thin solid film, 13 (2002) 403.

[2] R W Birkmire and E Eser, Ann Rev mater Sci, 27 (1997) 625.

[3] J L Shay and J H Wernick, Ternary chalcopyrite semiconductors Growth, electronic properties and applications (Pergamon Press, New York) 1975.

[4] A Chahed ,O Benhelas ,H Rozale,S Laksoni and N Abboeni , Phys Status solidi (b), 244 (2007) 629.

[5] L Garbato and A Rucci, Chem Phys Lett, 61 (1979) 542.

[6] L K Samanta, D K Ghosh and G C Bhar , J Chem Phys, 79 (1983) 361.

[7] A S Verma and S R Bhardwaj, J Phys condens Matter, 18 (2006).

[8] A S Verma and S R Bhardwaj, Phys. Status solidi (b), 243 (2006) 4025.

[9] A S Verma and S R Bhardwaj,, Phys script, 76 (2007) 22.

[10] A S Verma and D Sharma, Phys status solidi (b), 245 (2008) 678.

[11] A S Verma and A Kumar and S R Bhardwaj , Phys status solidi (b), 245 (2008) 1520.

[12] B F Levine , [a] Phys. Rev. B 7, (1973) 259; [b] J Chem phys, 59 (1973) 1463.

[13] H Neumann, [a] Crystal Res Technol 23, (1988) 97 [b] H Neumann Crystal Res Technol 24, (1989) 815.

[14] L Garbato L and A Rucci, Philo Mag, 35 (1977) 1681, 35 (1977) 1685.

[15] J C Phillip, Rey Mod Phys, (1970) 317.

[16] J A Van Vechten, Phys Rev, 182 (1969) 891.

[17] D S Chemla , Phys Rev letter, 26 (197) 1441.

[18] K L Samanta, and S Chatterjee, Phys Status sol (b) 182 (1994) K 85

[19] D Pines, Solid state physics 1st (edn.) F Seitz and D Turnbell (Academic Press NY), 367 (1955).

[20] D Pines, Rev Mod Phys, 28 (1956) 184.

[21] R Ferrel , Rev Mod Phys, 28 (1956) 308

[22] K S Srivastava,R L Srivastava ,O K Hansh and Y Kumar, J phys chem solids, 40 (1979) 489.

[23] D Pines, elementary excitation in solids (Benyamiior NY) 8 (1964).

[24] http://www.nims.go.jp/aperiodie/hrtem/recent/eels.

[25] Y Ohno, Phys Rev B, 46 (1992) B 46.

[26] S Narain, Phys status solidi (b), 182 (1994) 273.

[27] http://eprints gla.ac.vk/4716.

[28] J Robio and M Armientn, J Geo chem Explor, 68(2006) 167-181.

[29] K Widder , M Knupfer, O Knauff and J Frink, Phys Rev B, 5610 (1997) 154.

[30] M L Cohen, Phys Rev B, 32 (1985) 7988.

[31] S A Borshchevskii, N A Goryunova, F P Kesamanly and D N asdedov, Phys Status Solidi, 21 (1967) 9.

[32] H Neumam, Phys Status Solidi (b), 182 (1986) K 121.

[33] P Grima Gallardo Phys Status Solidi (b), 182 (1994) K 67.

[34] R R Reddy , Y Nazeer Ahammed ,K Rama Gopal ,TVR Rao ,P Abdul Azeem and P Mallikarjuna Reddy , Optical Materials, 14 (1983) 361 .

[35] R R Reddy, M Ravi Kumar and TVR Rao, Infrared Physics, 34 (1993) 95

[36] V P Gupta and V K Srivastav, J Phys. Chem Solids, 42 (1981) 1079

[37] V Kumar, G M Prasad and D Chandra Phys Status Solidi (b),186 (1994) K-454.

[38] P K Lam, M L Cohen and G Martinez, Phys Rev B, 35 (1987) 9190.

[39] R R Reddy, Y Nazeer Ahammed, K Ramagopal,D V Raghuram, Indian J pure Appl Phys, 37 (1999) 25.

Table 1 Plasmon energy, microhardness, bulk moduls of II-IV-V $\mathrm{V}_{2}$ ternary chalcopyrites

\begin{tabular}{|c|c|c|c|c|c|c|c|c|c|}
\hline & \multirow{2}{*}{$\begin{array}{c}\hbar \omega_{p} \\
(\mathrm{eV})\end{array}$} & \multirow{2}{*}{$\begin{array}{l}\text { Mol. } \\
\text { Wt. } \\
(\mathrm{g})\end{array}$} & \multirow{2}{*}{$\begin{array}{l}\text { Density } \\
\left(\mathrm{g} / \mathrm{cm}^{3}\right)\end{array}$} & \multicolumn{3}{|c|}{$\mathrm{H}\left(\mathrm{Kg} / \mathrm{mm}^{2}\right)$} & \multicolumn{3}{|c|}{$\mathrm{B}(\mathrm{GPa})$} \\
\hline & & & & $\begin{array}{c}\text { This } \\
\text { work } \\
\text { [eqn.(2)] }\end{array}$ & $\begin{array}{l}\text { expt. } \\
{[3,31]}\end{array}$ & $\begin{array}{c}\text { Reported } \\
{[5,18]}\end{array}$ & $\begin{array}{l}\text { This work } \\
\text { [eqn.(14)] }\end{array}$ & $\begin{array}{l}\text { expt. } \\
{[32]}\end{array}$ & $\begin{array}{l}\text { Reported } \\
{[13 a, 33]}\end{array}$ \\
\hline $\mathrm{ZnSiP}_{2}$ & 17.015 & 155.4 & 3.39 & 1061.35 & 1100 & 1065,900 & 114.10 & & 120 \\
\hline $\mathrm{ZnSiAs}_{2}$ & 16.085 & 242.2 & 4.7 & 808.72 & 920 & 890,820 & 94.733 & & 93 \\
\hline $\mathrm{ZnGeP}_{2}$ & 16.638 & 1.99 .9 & 4.179 & 958.94 & 980 & 770,635 & 106.25 & & 108 \\
\hline $\mathrm{ZnGeAs}_{2}$ & 15.663 & 248.8 & 5.32 & 694.09 & 680 & 680,630 & 85.94 & & 86 \\
\hline $\mathrm{ZnGeP}_{2}$ & 16.638 & 1.99 .9 & 4.179 & 958.94 & 980 & 770,635 & 106.25 & & 108 \\
\hline $\mathrm{ZnGeAs}_{2}$ & 15.663 & 248.8 & 5.32 & 694.09 & 680 & 680,630 & 85.94 & & 86 \\
\hline $\mathrm{ZnSnP}_{2}$ & 15.15 & 246 & 3.165 & 663.40 & 455 & 500,530 & 83.58 & & 84 \\
\hline $\mathrm{ZnSnAs}_{2}$ & 14.825 & 333.9 & 5.35 & 466.46 & 744 & 445,430 & 68.48 & & 67 \\
\hline $\mathrm{CdSiP}_{2}$ & 16.194 & 202.43 & 4 & 838.33 & & 765,730 & 97.00 & 97 & 97 \\
\hline $\mathrm{CdSiAs}_{2}$ & 15.35 & 290.34 & 5.154 & 609.07 & 565 & 640,615 & 79.41 & & 77 \\
\hline $\mathrm{CdGeP}_{2}$ & 15.517 & 246.94 & 4.48 & 654.43 & 470 & 515,470 & 82.89 & & 86 \\
\hline $\mathrm{CdGeAs}_{2}$ & 14.898 & 334.83 & 5.6 & 486.29 & & 490,470 & 70.00 & 70 & 70 \\
\hline $\mathrm{AgInTe}_{2}$ & 13.037 & 447.89 & 6.12 & 134.22 & 188 & 98,116 & 23.48 & & 28 \\
\hline $\mathrm{CdSnAs}_{2}$ & 14.092 & 380.93 & 5.72 & 267.35 & 335 & 315,310 & 53.20 & & 55 \\
\hline
\end{tabular}


Table 2 Plasmon energy, microhardness, bulk modulus of I-III-VI $\mathrm{I}_{2}$ ternary chalcopyrites

\begin{tabular}{|c|c|c|c|c|c|c|c|c|c|}
\hline \multirow{2}{*}{ Compounds } & \multirow{2}{*}{$\underset{(\mathrm{eV})}{\hbar \omega_{p}}$} & \multirow{2}{*}{$\begin{array}{l}\text { Mol. } \\
\text { Wt. } \\
(\mathrm{g})\end{array}$} & \multirow{2}{*}{$\begin{array}{l}\text { Density } \\
\left(\mathrm{g} / \mathrm{cm}^{3}\right)\end{array}$} & \multicolumn{3}{|c|}{$\mathrm{H}\left(\mathrm{Kg} / \mathrm{mm}^{2}\right)$} & \multicolumn{3}{|c|}{$\mathrm{B}(\mathrm{GPa})$} \\
\hline & & & & $\begin{array}{l}\text { This work } \\
\text { [eqn.(2)] }\end{array}$ & $\begin{array}{l}\text { expt. } \\
{[3,31]}\end{array}$ & $\begin{array}{c}\text { Reported } \\
{[5,18]}\end{array}$ & $\begin{array}{l}\text { This work } \\
\text { [eqn.(14)] }\end{array}$ & $\begin{array}{l}\text { expt. } \\
{[32]}\end{array}$ & $\begin{array}{c}\text { Reported } \\
{[13 a, 33]}\end{array}$ \\
\hline $\mathrm{CuAlS}_{2}$ & 17.25 & 154.65 & 3.47 & 219.88 & & 261,250 & 93.17 & & 94 \\
\hline $\mathrm{CuAlSe}_{2}$ & 15.845 & 248.45 & 4.7 & 191.31 & 210 & 228,226 & 69.93 & & 69 \\
\hline $\mathrm{CuAlTe}_{2}$ & 14.53 & 345.73 & 5.5 & 164.57 & 182 & 210,225 & 48.18 & & 45 \\
\hline $\mathrm{CuGaS}_{2}$ & 12.278 & 197.39 & 4.35 & 220.45 & & 245,230 & 93.63 & 94,96 & 93 \\
\hline $\mathrm{CuGaSe}_{2}$ & 15.918 & 291.19 & 5.56 & 192.80 & 197 & 210,197 & 71.14 & 71 & 68 \\
\hline $\mathrm{CuGaTe}_{2}$ & 14.305 & 388.47 & 5.99 & 160.00 & 180 & 185,240 & 44.45 & 44 & 43 \\
\hline $\mathrm{CuInS}_{2}$ & 16.123 & 242.44 & 4.75 & 196.96 & & 140,140 & 74.53 & & 71 \\
\hline $\mathrm{CuInSe}_{2}$ & 15.09 & 336.29 & 5.77 & 175.96 & 185 & 141,160 & 57.44 & 62 & 54 \\
\hline $\mathrm{CuInTe}_{2}$ & 13.664 & 433.57 & 6.1 & 146.97 & 152 & 140,166 & 33.85 & & 36 \\
\hline $\mathrm{AgAlSe}_{2}$ & 15.16 & 293.77 & 5.07 & 177.38 & 160 & 135,176 & 58.60 & & 55 \\
\hline $\mathrm{AgAlTe}_{2}$ & 14.501 & 390.05 & 6.18 & 163.98 & 149 & 142,167 & 47.70 & & 36 \\
\hline $\mathrm{AgGaS}_{2}$ & 16.098 & 241.71 & 4.72 & 196.46 & & 130,175 & 74.11 & & 70 \\
\hline $\mathrm{AgGaSe}_{2}$ & 15.199 & 335.51 & 5.84 & 178.18 & 150 & 124 & 59.24 & & 53 \\
\hline $\mathrm{AgGaTe}_{2}$ & 13.621 & 432.79 & 6.05 & 146.09 & & 142,166 & 33.14 & & 35 \\
\hline $\mathrm{AgInSe}_{2}$ & 14.233 & 380.61 & 5.81 & 158.53 & 127 & 82,102 & 43.26 & & 42 \\
\hline
\end{tabular}

Table 3. Electronic polarisability of II-VI- $\mathrm{V}_{2}$ ternary chalcopyrites.

\begin{tabular}{|c|c|c|c|c|c|}
\hline \multirow{2}{*}{ Compounds } & \multirow{2}{*}{$\begin{array}{c}\hbar \omega_{p} \\
(\mathrm{eV})\end{array}$} & \multicolumn{4}{|c|}{ Electronic polarisability, $\alpha \times 10^{-24}{ }_{\left(\mathrm{cm}^{3}\right)}$} \\
\hline & & $\begin{array}{l}\text { Present Study } \\
\text { (Eq.10) }\end{array}$ & [Ref. 34] & $\begin{array}{r}\text { Known } \\
\text { [Ref. 35] }\end{array}$ & [Ref. 36,37] \\
\hline $\mathrm{ZnSiP}_{2}$ & 17.015 & 13.21 & 12.27 & 12.45 & \begin{tabular}{l|r} 
& 10.70 \\
\end{tabular} \\
\hline $\mathrm{ZnSiAs}_{2}$ & 16.085 & 15.32 & 15.04 & 18.12 & 12.89 \\
\hline $\mathrm{ZnGeP}_{2}$ & 16.638 & 13.97 & 13.54 & 14.24 & 11.28 \\
\hline $\mathrm{ZnGeAs}_{2}$ & 15.663 & 14.09 & 16.82 & 20.52 & 12.62 \\
\hline $\mathrm{ZnSnP}_{2}$ & 15.55 & 23.50 & 14.54 & 16.36 & 13.80 \\
\hline $\mathrm{ZnSnAs}_{2}$ & 14.825 & 18.64 & 19.10 & 23.84 & 14.99 \\
\hline $\mathrm{CdSiP}_{2}$ & 16.194 & 15.00 & 13.58 & 14.34 & 12.29 \\
\hline $\mathrm{CdSiAs}_{2}$ & 15.35 & 17.14 & & 13.16 & \\
\hline $\mathrm{CdGeP}_{2}$ & 15.517 & 16.68 & 16.05 & 15.95 & 12.88 \\
\hline $\mathrm{CdGeAs}_{2}$ & 14.898 & 18.43 & 18.43 & 23.16 & 12.15 \\
\hline $\mathrm{CdSnAs}_{2}$ & 14.092 & 20.97 & 21.33 & 26.68 & 17.32 \\
\hline
\end{tabular}

Table 4. Electronic polarisability of I-III- $\mathrm{VI}_{2}$ ternary chalcopyrites.

\begin{tabular}{|c|c|c|c|c|c|}
\hline \multirow[b]{2}{*}{ Compounds } & \multirow{2}{*}{$\begin{array}{c}\hbar \omega_{p} \\
(\mathrm{eV})\end{array}$} & \multicolumn{4}{|c|}{ Electronic polarisability, $\alpha \times 10^{-24}\left(\mathrm{~cm}^{3}\right)$} \\
\hline & & $\begin{array}{c}\text { Present Study } \\
\text { (Eq.10) }\end{array}$ & [Ref. 34] & $\begin{array}{l}\text { Known } \\
\text { [Ref. 35] }\end{array}$ & [Ref. 36,37] \\
\hline $\mathrm{CuAlS}_{2}$ & 17.25 & 10.61 & 10.82 & 6.73 & 6.62 \\
\hline $\mathrm{CuAlSe}_{2}$ & 15.845 & 13.97 & 13.76 & 10.09 & 9.02 \\
\hline $\mathrm{CuAlTe}_{2}$ & 14.53 & 17.97 & 19.10 & 17.17 & 7.37 \\
\hline $\mathrm{CuGaS}_{2}$ & 12.278 & 10.78 & 12.06 & 7.25 & 7.61 \\
\hline $\mathrm{CuGaSe}_{2}$ & 15.918 & 13.78 & 15.27 & 10.91 & 10.29 \\
\hline $\mathrm{CuGaTe}_{2}$ & 14.305 & 18.76 & 19.7 & 19.20 & 11.74 \\
\hline $\mathrm{CuInS}_{2}$ & 16.123 & 13.24 & 13.29 & 8.43 & 10.59 \\
\hline $\mathrm{CuInSe}_{2}$ & 15.09 & 16.15 & 16.42 & 12.47 & 12.73 \\
\hline $\mathrm{CuInTe}_{2}$ & 13.664 & 21.22 & 22.63 & 20.86 & 15.29 \\
\hline $\mathrm{AgAlSe}_{2}$ & 15.16 & 15.93 & 13.68 & 11.31 & 10.42 \\
\hline $\mathrm{AgAlTe}_{2}$ & 14.501 & 18.07 & 16.07 & 19.35 & 12.06 \\
\hline $\mathrm{AgGaS}_{2}$ & 16.098 & 13.31 & 14.43 & 8.22 & 8.46 \\
\hline $\mathrm{AgGaSe}_{2}$ & 15.199 & 15.82 & 16.57 & 12.13 & 11.35 \\
\hline $\mathrm{AgGaTe}_{2}$ & 13.621 & 21.40 & 21.73 & 20.79 & 13.17 \\
\hline $\mathrm{AgInS}_{2}$ & 15.209 & 15.78 & 14.45 & 9.04 & 10.91 \\
\hline $\mathrm{AgInSe}_{2}$ & 14.233 & 19.02 & 20.08 & 13.51 & 14.69 \\
\hline $\mathrm{AgInTe}_{2}$ & 13.037 & 22.46 & 24.08 & 13.23 & 16.88 \\
\hline
\end{tabular}

